\title{
The SAMPLING AND Remix Dilemma: WHAT IS THE ROLE OF MORAL RIGHTS IN THE ENCOURAGEMENT AND REGULATION OF DeRIVATIVE CREATIVITY?
}

\section{ELIZABETH ADENEY*}

The borrowing and rearrangement of musical content, especially in the digital context, raises difficult questions for copyright law. There is significant community support for a loosening of the restrictions on the derivative (and particularly creative) use of copyright material. Law reform is called for. This paper discusses the possible introduction of a new exception to copyright infringement but notes that in the drafting of any such exception not only the economic rights but also the moral rights of the originating author need to be taken into account.

\section{INTRODUCTION}

It is probably true to say that music is, in our present society, the most widely and consistently consumed of the traditional art forms, having surpassed those more static arts based on the printed word or the still visual image in this respect. ${ }^{1}$ Judging by the popularity of YouTube, the moving image comes in second place to it. The consumption of both music and film has been greatly encouraged by the rise of digital media, a rise which has facilitated access to these expressive forms to such an extent that it has become effortless by comparison with what is still the most common way of accessing the written word - reading.

The digital media have also facilitated the generation of music and film, not just because they offer a convenient way in which sounds and moving images can be captured (useful to the original author), but because they enable the forms of expression which they store to be easily selected, detached from the whole, and reintegrated into a new work (useful to a derivative author). While the individual components of the new work are not generated by the derivative

\footnotetext{
* PhD German (University of Melbourne), PhD Law (Monash University); Associate Professor, Deakin University.

${ }^{1}$ Though of course the literary works which form the lyrics of songs are enjoying an associated popularity.
} 
author, their arrangement may well show sufficient originality for copyright to subsist in the derivative work under Australian law.

It is this derivative creativity, usually but not necessarily based on sound recordings and films, which has generated a whole new vocabulary reflecting new technological and artistic practices. The recently emerged concepts of 'sampling', 'mash-up', and 'remix' relate to the various ways in which preexisting works can be manipulated, alluded to, mutilated, altered, borrowed from, transformed, transposed, quoted, and incorporated into new creative forms. These acts can be carried out by anybody with the right software, and by children and adults alike. They are widely engaged in and disseminated, the dissemination as well as the creation being assisted by the digital medium in which the new work is stored.

It goes without saying that this offers major challenges to the law of Australia and to international copyright protection regimes. Those who practise and advise on law are likely to find its application to derivative creativity a difficult area. This is not because the law is particularly unclear (on the contrary, the questions of copyright subsistence and infringement generally follow a wellworn path, and the only surprises derive from how judicial decisions occasionally interpret the rules) but because what is an interesting and engaging contemporary creative practice gives rise to what might be thought a disproportionate amount of infringement.

Each national legislative scheme offers different ways of balancing the interests of the copyright holder and the derivative creator. Exclusive rights are given by the various copyright Acts and the taking and using of parts of a work are likely to mean prima facie infringement of both copyright and other author interests. However, exceptions to those rights are also established and are internationally sanctioned, or sometime required. ${ }^{2}$ Against the background of its international obligations, it is the role of the national legislator to find a path through the competing interests that is fair to all parties and achieves desirable social outcomes.

At present many would think that, particularly in the music field, the balance of interests represented by the Australian Copyright Act 1968 (Cth) is tipping too far to one side, giving too much to the copyright owner and taking too much from the copyright user. ${ }^{3}$ Community attitudes tend to favour the user of the

\footnotetext{
${ }^{2}$ For example the Berne Convention for the Protection of Literary and Artistic Works, opened for signature 9 September 1886, 828 UNTS 221 (entered into force 4 May 1896) art 9 sanctions the creation of exceptions as long as they conform to certain norms. Article 10 requires the freedom of quotation (again subject to certain norms).

${ }^{3}$ Though in some respects Australia's law may be liberal compared with that of the United States and Germany: see Bridgeport Music, Inc v Dimension Films 410 F 3d 792 (6 ${ }^{\text {th }}$ Cir, 2005) and
} 
copyright material, since that user is closer to home and has more emotional leverage in most people's lives than the copyright owner. Infringers and infringements are so many and so various that, even if a person is not infringing, that person is likely to know numerous other people who are. Furthermore, it may not be immediately obvious what detriment the infringement is causing or is likely to cause to the copyright owner. Under these circumstances support for the strict observance of copyright law tends to be lukewarm.

The factor that causes the greatest problems for policy and ethics in copyright circles is that this area of remixing is apt to pit author against author. It is a peculiarity of copyright law that a person can generate copyright in his or her own hands while at the same time infringing the rights of another author or copyright owner. The author-user then has two legal roles: he or she is protected by the system by virtue of engaging in the desirable activity of producing an original work, but is nevertheless an infringer against whom another author or copyright owner needs to be protected. Assuming that, from a policy point of view, the encouragement of art is a good thing - and most copyright systems seem to operate on the assumption that it is - it must be asked: 'Which art should be encouraged - the originating or the derivative art?' The problem is that most people concerned with author interests and, one suspects, society at large would like to support the interests of both.

\section{Parallel Rights - COPYRIGHT AND MoRAL RightS}

Under present Australian law, the two legal concerns when derivative creativity takes place are: 'Has copyright been breached?' and 'Have the moral rights of the author been breached?' The copyright part of the question asks 'Has the work been reproduced, published, performed in public, communicated to the public, or adapted?' or 'Has the sound recording or film been copied or otherwise disseminated?', all acts that might impinge on the copyright owner's economic interests. ${ }^{4}$ And the moral rights part of the question concerns itself with whether the originating author has received proper, accurate recognition;

Metall auf Metall, German Federal Supreme Court, I ZR 112/06, 20 November 2008. In both of those countries it has been decided, based on different principles, that the copying even of unrecognisably small portions of a sound recording (ie sampling) for artistic purposes is a potential copyright infringement. In Australia it seems likely that the substantial part principle would prevent such a finding.

${ }^{4}$ Copyright Act 1968 (Cth) s 31. 
and whether that person's work has been used in a way that maintains his or her honour and/or reputation. ${ }^{5}$

These two last areas of moral rights - the recognition of the author and the preservation of author interests though preservation of the work - necessarily become urgent in any field where the subject matter is digitised.

In relation to the naming of the author, whenever an author's work is fragmented, shredded, taken apart, turned into the building block/s of another work, the prospects of its authorship being properly recognised and attributed decrease and the likelihood of it being used in ways which are offensive to the originating author considerably increase. The ease with which this can be done increases the problem.

In relation to the use or treatment of the work, many acts can impinge on the author's honour or reputation. The work, whether dismembered or complete, could be used in an offensive political context, for example. Or a work could be used for advertising purposes which are distasteful to its author even though its copyright owner has no objection. It may even be the copyright owner who is engaging in the offensive uses of the work. The work might be distorted or amended in a way that the public might associate with the original author, to his or her detriment. Or the distortion might just disrespect the creative vision of the originating author. The treatment of the work may be intended to express malice or contempt towards its author. Alternatively, the user, in the grip of his or her own creative impulse, may not be focused on the personality of the originating author at all, but rather on whatever creative communication the user is wanting to make.

\section{MORAL Rights in the Remix CULtURE}

The moral rights area is an emerging area of jurisprudence in Australia, since the courts are dealing with provisions which have been in operation only since $2000^{6}$ and which have until now generated little litigation.

The questions of remixing, and of the operation of moral rights where a remix has occurred, have been discussed in one Australian court recently, in the music context. The right in issue in the case was the right of integrity of authorship (an

\footnotetext{
${ }^{5}$ Copyright Act 1968 (Cth) ss 193, 195AC, 195AI and associated sections. This applies to authors of all kinds of 'work' and also authors of cinematograph films (defined as works for moral rights purposes). It does not apply to producers of sound recordings.

${ }^{6}$ Copyright Amendment (Moral Rights) Act 2000 (Cth).
} 
earlier judgment, though not concerned with musical issues, had upheld the right of an author to correct attribution). ${ }^{7}$

In February 2012 the American musician Armando Perez, who uses the stage name Pitbull, was - in an international moral rights action - able to win his case against an Australian DJ/promoter, Jaime Fernandez, who had altered the beginning of one of his songs in a way that was offensive to him and, he alleged, damaging to his reputation. The case, Perez $v$ Fernandez, ${ }^{8}$ was decided in the Federal Magistrates Court, and invoked the right of integrity of authorship.

The alteration which had occurred was an unauthorised remix. The opening words of Pitbull's original arrangement, Bon, Bon, had been deleted from the song and replaced with 10 seconds of an audio drop (a recording of words spoken by Pitbull and sent to the respondent by Pitbull) which associated the respondent with the hip-hop artist. The association had once been real enough, since Pitbull had been planning a trip to Australia with Fernandez as his promoter, but the trip had been cancelled and the two parties had been engaged in litigation. ${ }^{9}$ The remixed song was streamed on Fernandez's website for a short period of time and he had also played it at nightclubs.

The Magistrate decided that this cutting and pasting of material from the audio drop into the song, and the removal of material from the song, amounted to a material distortion or alteration, if not a mutilation of the musical work. ${ }^{10} \mathrm{He}$ then considered whether the act had been prejudicial to Pitbull's honour or reputation. One factor taken into account was that an audience unfamiliar with the song might well have thought that the alteration was Pitbull's own doing and that he had deliberately associated himself in the musical work with the DJ Fernandez.

The Magistrate accepted that '[a]rtists go to great lengths to choose whom they associate with, and these associations form a central part of their reputation'. ${ }^{11}$ He accepted that 'Mr Perez himself strongly considered [the association with the DJ] to be prejudicial to his reputation, ${ }^{12}$ and that it caused him 'anger and

\footnotetext{
${ }^{7}$ Meskenas v ACP Publishing Ltd (2006) 70 IPR 172.

${ }^{8}$ [2012] FMCA 2.

${ }^{9}$ Ibid [2], [37].

${ }^{10}$ Ibid [84].

${ }^{11}$ Ibid [87].

${ }^{12}$ Ibid.
} 
distress ${ }^{13}$ to have been associated with Fernandez in this way. In other words, the Magistrate was prepared to take into account both evidence of the subjective feelings of the applicant and more objective evidence concerning what was likely to be important to a hip-hop artist.

The Magistrate also looked at the likely response of an audience more familiar with the song and the circumstances of its alteration. He considered that such an audience would see that the remix had been used in a way which mocked Pitbull or his reputation ${ }^{14}$ and attempted to secure an advantage for Fernandez. ${ }^{15}$ Again, anything which caused such perceptions to arise would be prejudicial to Pitbull's honour or reputation.

But did any defence apply? Under Australian law the primary defence to an allegation of moral rights infringement is that the act in question was reasonable under the circumstances. ${ }^{16}$ This defence is available where the integrity right has allegedly been infringed, as in this case. However, the Magistrate did not accept that the defendant's actions were in any way 'reasonable'. As required by the Act, he went through the factors to be taken into account in determining reasonableness. ${ }^{17}$ The first factor, the nature of the work, he approached by stating that this work existed in a genre in which associations between artists are of considerable significance. The second, the purpose for which the work was used, he approached by stating that the purpose was either to promote $\mathrm{Mr}$ Fernandez for his own benefit or to mock Mr Perez as an act of retribution. The third, the manner and context in which the work was used, he approached by noting that this included the fact that the work was streamed from Fernandez's own website. He also considered the existing, poor, relationship between the parties to be part of the context in which the work was used. ${ }^{18}$ The upshot was that the alteration to and subsequent use of the altered musical work had not been reasonable in the circumstances and the integrity right had been breached. Thus, the moral rights had been used here to control one type of creative remix.

\section{COPYRIGHT AND MUSICAL APPROPRIATION}

Copyright law (as opposed to moral rights law) has also been used in Australia against a type of musical remix - again with a negative outcome for the remixer. The case in question was this time concerned not with the work into

\footnotetext{
${ }^{13}$ Ibid.

${ }^{14}$ Ibid [57], [88]-[89].

${ }^{15}$ Ibid [69].

${ }^{16}$ Copyright Act 1968 (Cth) ss 195AR, 195AS.

${ }^{17}$ Perez v Fernandez [2012] FMCA 2 [89].

${ }^{18}$ Ibid.
} 
which interpolated material had been brought, but the work from which the interpolated material had been taken. The case in question was EMI Songs Australia Pty Ltd v Larrikin Music Publishing Pty Ltd, ${ }^{19}$ which has been the most high profile legal case of musical borrowing in Australia, and which has drawn a great deal of criticism. The matter was finally resolved by the Full Federal Court. $^{20}$

What had happened was that two bars of copyright music from a well-known children's round (Kookaburra Sits in the Old Gum Tree) were taken by Greg Ham of the band Men at Work and used in one of his original musical compositions, the 'rock anthem' Down Under. The copyright owner of Kookaburra took action for copyright infringement, alleging that a substantial part of the musical work had been taken. The infringement was made out, since there was little doubt that a substantial part of the copyright work had been reproduced, recorded, and commercialised by the band. None of the existing defences to copyright infringement - that there had been a fair dealing for the purposes of research or study, criticism or review, or reporting the news ${ }^{21}$ were argued in the case, since none of them appeared applicable. (The more recent defence that there had been a fair dealing for the purposes of parody or satire did not exist at the relevant time and would, in any event, have been difficult to establish.) ${ }^{22}$ The outcome caused significant disquiet in the musical and broader communities, since it was widely felt that what the band had done was both trivial and artistically acceptable. Although the work was still in copyright, the author was long dead. One of the judges of the Full Federal Court expressed his unease at the outcome, suggesting that changes to the law might be appropriate. ${ }^{23}$

\section{THE IMPETUS For LAW REFORM - THE PRESSURE POINTS}

When the question of derivative creativity is considered, it is on this type of situation - namely copyright infringement and defences to it - that pressure for law reform is likely to focus for the time being. Copyright law tends to be

\footnotetext{
${ }^{19}$ (2011) 90 IPR 50 ('EMI Case’).

${ }^{20}$ The High Court subsequently refused leave to appeal: EMI Songs Australia Pty Ltd v Larrikin Music Publishing Pty Ltd [2011] HCATrans 284.

${ }^{21}$ Copyright Act 1968 (Cth) ss 40-42.

${ }^{22}$ Copyright Act 1968 (Cth) s 41A.

${ }^{23}$ EMI Case (2011) 90 IPR 50, [98], [100].
} 
the target for the anger of those who promote derivative creativity. This is arguably because copyright often resides in corporate entities which do not attract the intuitive sympathy that natural persons do. Nevertheless, if anger at the outcome in the EMI case causes a readjustment of copyright law, that readjustment will have implications for moral rights too. The two areas are much too closely interlinked for that to be avoided. It is not necessarily the case, however, that the effect on moral rights will be negative.

There are several aspects of copyright that are currently taking the weight of popular disapproval around the world, and particularly with regard to musical creativity. It is worth considering for a moment the major current challenges to copyright law and their implications for moral rights.

\section{The Copyright Term}

Foremost among the bones of contention is the copyright term, which in Australia is 70 years after the death of the author, as a rule of thumb. ${ }^{24}$ This is consistent with the copyright term in the United States and Europe. ${ }^{25}$ It is argued that copyright lasts for far too long. The implication is that if the term of protection were shorter, the various constraints that it places on derivative creativity would be less of a problem.

This was the view taken by Emmett $\mathrm{J}$ in the EMI case. '[I]t may be', he said 'that the extent of that monopoly, both in terms of time and extent of restriction, ought not necessarily be the same for every work'. ${ }^{26}$

Concerns about the copyright term have also been central to the arguments of the various national manifestations of the Pirates Party that have recently come to the fore around the world and have a prominent voice in the anti-copyright (or copyright reform) movement. Thus, the German Pirates Party demands a copyright period of 10 years from the death of the author ${ }^{27}$ — quite a modest demand in one sense, since the author may live a long time. It is, however, dramatic in Berne Convention terms, which sets a minimum term of 50 years post mortem auctoris. ${ }^{28}$ (It is unclear how such a shortened term would benefit

\footnotetext{
${ }^{24}$ Copyright Act 1968 (Cth) s 33.

${ }^{25}$ Council Directive 2006/116/EC of 12 December 2006 on The Term of Protection of Copyright and Certain Related Rights [2006] OJ L372/12 art 1; Copyright Law of the United States of America, 17 USC Ch 3 (1978), particularly § 302.

${ }^{26}$ EMI Case (2011) 90 IPR 50 [100].

27 Piratenpartei, Die zehn wichtigsten Punkte einer Urheberrechtsreform (21 May 2012) $<$ http://www.piratenpartei.de/2012/05/21/zehn-punkte-urheberrechtsreform/>.

${ }^{28}$ Berne Convention for the Protection of Literary and Artistic Works, opened for signature 9 September 1886, 828 UNTS 221 (entered into force 4 May 1896) ('Berne Convention') art 7(1).
} 
most of those who are currently engaging in digital remixes. By the time the author (often young at the time of composition) has been dead 10 years, the public interest in most works will have disappeared.) By contrast, the Dutch Pirates Party has demanded, on its website, a commercial copyright term of five years maximum, ${ }^{29}$ presumably from creation or publication. This would be very dramatic indeed and certainly a term that would promote derivative creativity, though it might also kill off the recording and film industries that rely on copyright.

I do not think any such reduction in the copyright term is going to happen soon, but if the copyright term were reduced even a little, would that have an effect on the author's moral rights? In fact it would not necessarily have any effect, since there is no inevitable linkage between it and the moral rights term. Moral rights protection can be perpetual, as it is theoretically in France. ${ }^{30}$ Or it can be linked to the copyright term, as it is in Germany and the United Kingdom. ${ }^{31}$ Or it can under some circumstances last only for the life of the author as it does for the integrity right in relation to films in Australia. ${ }^{32}$ How the moral rights term would be treated in the event that the copyright term was shortened would be largely a matter of domestic policy. In any event the control that moral rights exert over the utilisation of a work will not inevitably be reduced with any reduction of the copyright term.

\section{THE EXCEPTIONS TO INFRINGEMENT}

Another area that bears the weight of disapproval is that of defences or exceptions to copyright infringement. In Australia our exceptions are very narrow - too narrow to protect Greg Ham. Although they were recently expanded by the introduction of an exception for the purposes of parody or satire, the Australian Law Reform Commission (ALRC) is again considering ways in which these exceptions might be expanded so as to be more serviceable

${ }^{29}$ Piratenpartij Nederland, Piratenpartij Nederland Partijprogramma (20 July 2012) 24 [5.3] $<$ http://www.piratenpartij.nl/partijprogramma>.

${ }^{30}$ Code de la propriété intellectuelle (France), art L121-1.

${ }^{31}$ Urheberrechtsgesetz (Germany) s 64, giving a term of 70 years after the author's death, applies to authors' rights as a whole, of which moral rights are part. This is due to the 'monist' concept of authors' rights in Germany whereby all are part of the one whole. The Copyright Designs and Patents Act 1988 (UK) s 86(1) expressly gives moral rights the same term as copyright.

${ }^{32}$ Copyright Act 1968 (Cth) s 195AM(1). 
in the digital context. ${ }^{33}$ No doubt representations will be made that the use of a copyright work as a basis for derivative creativity or transformative use should form some kind of exception.

Such a representation has already been made overseas. In the Netherlands the Pirates Party has demanded that the non-commercial combining, alteration and remixing of existing copyright-protected material should be permissible on the basis of its promotion of culture, art and science. ${ }^{34}$ The old and rather too simple argument is raised in the Dutch manifesto that all creations are a mix of previous creations anyway and copyright should not have a chilling effect on the culture. (This argument is too simple because, generally speaking, the works which copyright protects are made up of a mix of previous ideas, which are free anyway. It is still not the norm for them to be a mix of previous expression, despite the intertextuality of postmodern art. In that sense they are generally not a mix of previous works at all.) In cases of commercial derivative use the Netherlands Pirates Party seems to envisage a compulsory or statutory licence existing. ${ }^{35}$

It remains to be seen whether a remix exception would be introduced in Australia. It has no express basis in the Berne Convention ${ }^{36}$ and it may be a little too specific to a particular artistic genre to be able to gain traction. Instead, what might be used to address circumstances such as the one raised in the EMI case is a general quotation exception, which is hardly controversial, the Berne Convention expressly requiring a freedom of quotation. ${ }^{37}$ (In fact Australia may be in breach of Berne in not providing such a freedom.) An exception of this kind was mooted in the paper produced by the Copyright Council Expert Group in $2011 .^{38}$

Such an exception would or should apply to musical as well as literary, dramatic and artistic works, and would allow either parts of a work or sometimes the whole of a work to be incorporated into another work for quotation purposes. Thought would need to be given to what a quotation purpose is, but such an exception would have the capacity to cut across Australia's current notoriously rigid exceptions to copyright infringement. There is no reason why the

${ }^{33}$ ALRC, Copyright Inquiry: Copyright and the Digital Economy, Issues Paper No 42 (2012) $<$ http://www.alrc.gov.au/inquiries/copyright-and-digital-economy>.

${ }^{34}$ Piratenpartij Nederland, above n 29, 24 [5.4].

${ }^{35}$ Ibid.

${ }^{36}$ Berne Convention, above n 29.

${ }^{37}$ Ibid art 10.

38 Copyright Council Expert Group, Directions in Copyright Reform in Australia (2011) $<$ http://www.copyright.org.au/pdf/Copyright\%20Council\%20Expert\%20Group\%20-

\%20Paper\%202011.pdf>. 
allowable quotation purposes should not extend to the use of the work in an artistic context and even in a commercial artistic context, within certain constraints. Since the use of the Kookaburra extract in Down Under was almost certainly a quotation (incorporated to make a point, to fix the quoting song in time and place), it would arguably be saved by such an exception.

One of the constraints that would need to apply to the exception is that the taking would have to be a genuine quotation, not just a plundering of the source work for those parts of its content that are likely to be attractive to the marketplace (and ways would have to be worked out to determine this). Another crucial constraint is that the author's other rights would have to be observed. Those other rights would be the moral rights.

If a new exception is to be introduced into Australian law, the type of interaction between the exception and moral rights needs to be considered. How applicable are moral rights in instances where the user is relying on one of the copyright exceptions, whether it be an existing exception or a mooted exception? We can take some guidance from the Berne Convention which expressly addresses this issue. The exceptions provisions in the Convention are contained mainly in arts 9 and 10, together with art 10bis.

Under art 9 any exception legislated for by a Berne Union member must not 'unreasonably prejudice the legitimate interests of the author' (emphasis added). There is no more legitimate interest than a moral rights interest, which is indeed expressly recognised as a right both by international treaty and by domestic law. Under art 10, which mandates the freedom of quotation, 'mention shall be made of the source, and of the name of the author if it appears thereon'. In other words the attribution right is maintained, after a fashion.

The otherwise iconoclastic Dutch Pirates Party likewise deals with the attribution issue by requiring in its manifesto that remixes must, where this is feasible and reasonable, be accompanied by an indication of their source. ${ }^{39}$ The German Pirates Party claims to give full recognition to the personality (moral) rights of authors. Its quarrel is only with copyright. ${ }^{40}$ And in current European

\footnotetext{
${ }^{39}$ Piratenpartij Nederland, above n 29, 24 [5.5].

40 'We fully recognise the personality rights of authors with regard to their work': Piratenpartei, above $\mathrm{n} 27$ (author's translation).
} 
statutes exceptions to infringement are expressed in a variety of ways to be subject to the moral rights or personality rights of the author. ${ }^{41}$

So how would moral rights be treated if the exceptions were expanded in Australia? One point to be made is that, by contrast with certain statements that are made in Europe (where moral rights tend to be considered the foremost of the bundle of authorial rights), ${ }^{42}$ moral rights in Australia do not take precedence over copyright in cases of conflict or doubt. But neither does copyright take precedence over them. Moral rights are independent statutory rights additional to copyright; they are not exceptions to rights; they are not in any sense secondary to copyright; there is no principle under which they should be interpreted narrowly.

\section{Problems With Reliance on the Reasonableness TEST}

Perhaps we can derive a better idea of what should happen here in the future if we look to the recent past.

Not long ago in Australia a new parody or satire exception (fair dealing for the purposes of parody or satire) was introduced, clearly to enhance freedom of speech and of artistic expression and to promote one type of derivative creativity. ${ }^{43}$ The exception operates solely to save a person who has allegedly infringed copyright. When it was introduced, it was not expressed to interact with the moral rights in any particular way, any more than the other exceptions are, the Act being silent on any interaction. Since nothing in the Act impinges on the moral rights, this leaves them intact and operative.

Prima facie, then, if a work were reproduced for satirical or parodic purposes it would still be necessary to name the original author, not to make any false attribution, and not to alter or transpose the work in a prejudicial way. On the other hand alterations or non-attributions that were reasonable in the circumstances would be saved from moral rights infringement, since this limit is built in to the moral rights provisions themselves. It is arguable, however, that an alteration or transposition for parodic or satirical purposes could not by

\footnotetext{
${ }^{41}$ See further below $n 42$.

${ }^{42}$ A point made, in relation to French law, by Sylvie Nérisson, Le droit moral de l'auteur décédé en France et en Allemagne (Institut de Recherche en Propriété Intellectuelle, 2003) 23; H Desbois, Le droit d'auteur en France (Dalloz, $3^{\text {rd }}$ ed, 1978) 380; P Sirinelli in note to Bragance c Olivier Orban et Michel de Grèce, CA Paris ch 1, (1989) 142 RIDA 301, 319.

${ }^{43}$ Copyright Act 1968 (Cth) s 41A as inserted by Copyright Amendment Act 2006 (Cth) s 3 sch 6 item 9A. These amendments came into force 11 December 2006.
} 
definition be reasonable, taking into account the personal interests of the author and the fact that courts are prepared to look at the author's subjective feelings when considering author prejudice (as has been seen in the recent case of Perez $v$ Fernandez). How can it be reasonable, in a moral rights context, to undermine a person's reputation in the way that parody or satire is apt to do?

So on the one hand public policy - the interest in free speech, or the interest in freedom of artistic expression and development - provides reasons why a parody or satire might be reasonable. And on the other hand the prejudice to the honour or reputation of the author, which can so easily be caused by a use of a work out of context for parodic or satirical purposes, is the very kind of thing that the moral right of integrity is constructed to guard against.

With the introduction of a parody or satire exception being superimposed on the existing notion of a reasonable use of a work, the legislature seems to have put courts into a position where they are going to have to make some quite difficult decisions one day. For this reason it would be desirable for any further exceptions generated by the digital environment and by postmodern musical practice to be expressed in a way that takes a stance on the moral rights question and does not leave the whole weight of the problem resting on the word 'reasonable'.

If we were to learn from our European counterparts, we would make our exceptions to copyright infringement contingent on the moral rights of the author being respected. In Austria, for example, quotations from musical works (such as the Kookaburra extract) are permitted, but there is an express requirement protecting the author's personality rights in these instances. ${ }^{44}$ German law also indicates that copyright exceptions are subject to respect for the personality (moral) rights of the author. ${ }^{45}$ In Australia, if we were to introduce a quotation or remix exception we could make it subject to the requirement that the original author's name be mentioned in association with the

\footnotetext{
${ }^{44}$ In that country the author's right of integrity (as well as the attribution right) is explicitly preserved in instances where the quotation exception applies. Protection of the right of integrity is achieved in this context by Urheberrechtsgesetz (Austria) s 57 which refers back to s 21 which in turn deals with permissible and impermissible alterations to the work. Section 57(1) itself also states that the 'meaning and nature of the work that has been used may under no circumstances be distorted'.

${ }^{45}$ Urheberrechtsgesetz (Germany) s 63 makes the liberty to quote subject to the requirement that the source of the quotation be acknowledged. In addition, the more general moral right of attribution ('recognition of authorship') in s 13 states the right of the author to be recognised as such.
} 
work, at least when the derivative work was going to be communicated to the public or otherwise disseminated. This is, after all, not so very onerous a condition to apply. Even a child could do it, and children are many of the most active infringers. The omission of any attribution whatever is what rendered unacceptable the actions of the band Men at Work when they chose to quote the work of the Kookaburra author, Marion Sinclair.

The existence of such a provision would put to rest any doubts about whether it was 'reasonable' not to name the original authors when a composite or remixed work was created. Similarly, it should go without saying, but might as well be stated, that there should be no false attribution of authorship in the remixing context. In other words the borrowed portion should not be passed off as the work of the remixer, something which would occur almost automatically where proper attribution has not been made. And it should not be reasonable for the honour or reputation of the original author to be prejudiced through the context in which the original work is now used, the environment in which it now appears, or the type of alterations that have been made to it.

\section{CONCLUSION}

When looking at law reform in the digital context, what we are focused on is a balancing of the system and a balancing of interests. If user-authors wish to be treated with respect and to have the balance adjusted in their favour, then they need to accord that respect to the primary authors whose work they may be allowed to appropriate. Similarly, those who enjoy the derivative work and wish to run a freedom of art/freedom of speech type argument - in other words a human rights argument - need to respect the human rights of those who have provided the source material. ${ }^{46}$

So what one would hope to see in the future is a scenario in which moral rights set the point beyond which exceptions to copyright, whatever they may be, cannot go. The rights would not exist in the Act as inconvenient provisions that nobody quite knows what to do with, a position that they may have occupied for their first decade. They would have the positive function of expressly curbing the excesses of copyright law, whatever path it may take, by reference to fixed values. And those values would be protective of the person without whom no creativity exists — the author.

46 Rights (to the moral and material interests in the work) which are provided for in the International Covenant on Economic, Social and Cultural Rights, opened for signature on 16 December 1966, 993 UNTS 3 (entered into force 3 January 1976) art 15(1)(c). 